\title{
Using New Media in Teaching English Reading and Writing for Hearing Impaired Students- Taking Leshan Special Education School as an Example
}

\author{
Bo Xu \\ School of Foreign Languages, Leshan Normal University, Leshan, Sichuan, China
}

\begin{abstract}
Based on socio-cultural interactive mode, this paper attempts to teach reading and writing for hearing impaired students in senior high special education school via new media, such as multimedia technology, smart cell phone, Ipad ,wechat, Mooc, microblog, etc. which facilitates acquisition mode of hearing impaired students. This paper constructs an interactive mode in which teacher teaches hearing impaired students English reading and writing through multimedia in class on-line and students learn English via smart cell phone, Ipad, wechat, Mooc, Microblog off-line. The online and offline class constitutes a whole learning mode for them. Through this mode, this paper puts forward some strategies and methods to train reading and writing competence for hearing impaired students.
\end{abstract}

Index Terms - new media, smart cell phone, mobile apps, English reading and writing, hearing impaired students

\section{INTRODUCTION}

Hearing impaired student is also called deaf person. There has been a controversy between oral English teaching and sign language teaching for hearing impaired students in China. Many scholars in China tries to train hearing impaired students English competence through English teaching methods for general students, but it is difficult for them to overcome phenomenon such as vocabulary memory vagueness, incomplete sentence element, linguistic vagueness and bad study habits etc.

Hearing impaired students has an English learning mode different from normal hearing person. Sign language is their first language, Chinese is their second language and English is the third language. The grammar and vocabulary is quite different among sign language, Chinese and English. English learning for hearing impaired students involves trilingual environment, i.e. the conversion among written Chinese, Chinese sign language and English, among which written Chinese and Chinese sign language is a complementary language. Due to restriction of hearing and shortage of pronunciation, hearing impaired students are mainly dependent on visual input and word output to learn English. As for teaching content, written English is the focal point for teaching and learning.

Hearing impaired students in special education school have their own characteristics. They learn English through reading and writing, and teacher teaches the via reading and writing. Thus, teaching mode is traditional. Nowadays, our nation and Sichuan province attach importance to special education.

Therefore, it is necessary to reform teaching and learning mode for hearing impaired students via new media, such as multimedia technology, Mooc, Ipad, wechat, microblog, QQ, etc. This paper tries to construct a mode for teacher and hearing impaired students so that their interests of learning can be aroused and consequently, improve their English reading and writing competence.

Twelve hearing impaired students are selected to participate in our survey. Before providing them with smart phones or Ipad, we gave them a reading and writing test. Then, 4 months later, we gave them the same reading and writing test to see the score variations. More specifically, this study addresses the following questions:

1. Does the new media intervention improve hearing impaired student's English reading or writing skills?

2. Does the new media improve teaching and learning effectiveness for teacher and hearing impaired student?

3. What are the advantages of and challenges to using new media for classroom instruction and learning?

\section{LITERATURE REVIEW}

Scholars both at home and abroad conducted research on English teaching for hearing impaired students; some of them study English learning for hearing impaired students.

Tu Chunlei (2006) put forward three points to train hearing impaired students linguistic competence. Number one is to penetrate linguistic training in teaching. Number two is to strengthen reading comprehension in comprehensive application. Number three is to create a chatting environment for communication via cyber chatting. 
Zhang Songbai (2009) argued that English as a foreign language learners in China mainly consist of the hearing normal and the hearing impaired. Up till now, plenty of researchers have devoted much efforts and made great contributions to the former whereas the study of the latter remains the undeveloped field even today. He did an empirical study in which a natural English class was observed and four systematical interviews have been done. 108 students from three special education schools have done the questionnaire. Research results shows that the Chinese hearing impaired learn English as a foreign language mainly via the visual-manual channel; learning and teaching focus is written English ; the Chinese hearing impaired learn English in trilingual environment: Chinese Sign Language, Chinese and English, which helps the hearing impaired students in learning English. On the basis of the findings of the study, the suggestions and implications for EFL teaching of the hearing impaired in China are proposed.

Sun Zhifang, et al(2012) maintained that , on the basis of grasping the characteristics of multimedia technology, the application of multimedia technology in English teaching in special education can effectively compensate for the hearing impaired students, help them overcome their self-abased psychology, and develop their logical thinking ability. Multimedia technology can create digital learning environments for English learning by extending students' vision, highlighting the role of object teaching, thereby enhance the students' self-study ability. The teacher should put emphasis on avoiding some of the disadvantages of multimedia technology while using multimedia technology to optimize teaching methods and improve students' interests.

Song Bo (2012) applied Interactive Whiteboard to hearing impaired students English teaching. Based on specific teaching content, he finds out the advantages and features of interactive whiteboard in creating teaching situation, class interaction and effective encouragement.

Xue Qing (2012) thought that multimedia is a vivid effective direct modern teaching means, which makes the English class interesting and colorful. Owing to audio-lingual damage, hearing impaired students have great difficulty in listening and speaking. Multimedia can help them to read and strengthen their reading and writing ability, optimize the structure of English class and improve teaching efficiency greatly.

Zhu Lei and Xin Wei (2013) put virtual reality technology into English learning project for going abroad, which testifies that it enables students to exploit the visual compensation advantage to the full and stimulate their learning interests, improve teaching quality, and it is of great significance to reform teaching mode for hearing impaired students.

Wang Xincheng (2014) argued that it is a challenging job to teach hearing impaired students English. Effective English teaching is the common objective for teachers and students. He made an analysis of English teaching for hearing impaired students from the perspective of effective teachers, integrating English textbook, using auxiliary teaching means and teacher and student's reflection.

Wang Zhengsheng(2014) argued that special educators have opened up the area of English teaching for deaf students in China, and has achieved certain goals in research and practice: designing the English course; and exploring English teaching methods for the hearing impaired students and the characteristics of their English learning, and so on. The future teaching research and practice need to strengthen the study of curriculum, emphasize the research into hearing impaired English learners, enrich the teaching methods, and combine modern information technology with English teaching for hearing impaired students.

On the basis of teaching mode of constructivism, Li Xiang (2014) made an exploration of special education English teachers development in order to improve people's cognition of the importance of special education English teachers development, thus , facilitating the balance and sustainable development of special education.

Zou Xiaowei(2014) maintained that traditional course teaching mode can not meet the needs of the era. It is of great practical and theatrical significance to make an innovation of it in the new era. Scientific and human-oriented teaching system will be produced by teaching reform. He made an analysis of limitation of the traditional teaching mode of English major, and explored the necessity of innovation study of it, and discussed the advantage of innovation in the new media era, finally, he put forward some relevant strategies.

Based on the application of new media in English teaching, Chen Ruojing (2015) discussed that double interactive teaching mode, modern blended teaching mode under the condition of new media thus, puts forward strategies for English teaching, which coordinates the unity of new media and English education. Consequently, the modernization of English education is achieved.

HE Gao-da (2015) argued that second language acquisition research has been a hot topic in the global linguistics studies in the past 50 years. The development of technology, Internet and ICT in particular, expand the space and approaches to second language acquisition. Technology transforms the storage, presentation and transportation of knowledge, so visual knowledge becomes a trend. Visual knowledge changes the ways the learners acquire knowledge, optimizes the approaches to acquiring knowledge and processing of information, and thus may raise the efficiency of learning.

Zhao Chun hui and $\mathrm{Hu}$ Zhen Bo (2015) discussed the situation of higher special education in China and the advantages of multimedia network teaching. The application of network technology in the special education offers the teaching and learning methods and techniques for the disabled and helps them in their learning. So teachers should take good advantage of this opportunity, spare no effort to create a good teaching environment, construct information education mode, use the modern education technology, summarize experience constantly, improve the modern education technology in special education. 
Yu Jing (2015) deemed that efficient and rapid digital technology and mobile teaching mode can help hearing impaired students free from the restriction of time and space, which realizes the vividness, interaction and autonomy and pluralism of English class and thus brings a totally new experience for English learning.

Zheng Xuan (2016) maintained that learning English plays a positive role in hearing impaired person's obtaining information, communicating with people and self-improving. Parents and teachers need to improve expectation for hearing impaired students English learning. Abiding by education rules, teachers can improve students English through interest motivation, memorizing words while using hand and mouth, and drawing inferences.

With the rapid development of global information and network technology, teachers need to create life-centered teaching situation via computer and network technology. Teachers also can make use of the online assessment and mini-video to arouse hearing impaired students' interest in extracurricular reading. Zhou Lin (2016) integrated IT into extracurricular English reading through teaching strategies of guiding them self-reading and second-time reading. Therefore, hearing impaired students learn English by doing, which shows the value and significance of English teaching in special education school?

Scholars in China mainly applied multimedia, electronic whiteboard, virtual reality technology, situational language teaching to English teaching for hearing impaired students, which focuses on teaching method ,teaching mode to study English teaching for hearing impaired students. Currently, no scholars in China has done a study on learning and teaching mode of English reading and writing from the perspective of new media. So it is necessary to conduct a study on it.

Patricia O'Malley et al. (2014) inquired into the effects of using iPads in a class wide academic intervention to increase independent task completion and basic math skills of seven students diagnosed with autism spectrum disorders (ASD) enrolled in a special education school The advantages of and challenges to using iPads for classroom instruction are also discussed in the study. They find out that iPads can be an effective instructional tool to enhance learning and independence.

Camille Rogers and Bruce Rogers (2013) examined how IPads and software applications are being used by K-12 special education teachers, speech pathologists, and school psychologists to aid with teaching, learning, and development of special needs students. How IPads are used to assist students with speech impediments, autism, reading skills, and math development is also expounded in the study.

Genevieve Marie Johnson (2013) found out that, generally, teachers and assistants thought that iPads were good for children with special needs, particularly for children with autism, attention deficits and limitations of fine motor control. Special education teachers and teacher assistants pointed out that using iPads can promote student language and literacy skills. One benefit of using tablet computers in school is that it can enhance student motivation. A tablet computer is an essential aspect of individual program plans. Downloading and organizing specific applications on specific children's tablets might be the teaching tasks and professional development might be the focus of evaluation of tablet applications.

Therese M. Cumming (2013) probed into the using of iPad tablets in the language arts lessons of four elementary school students with language-based disabilities. Using the iPad helped the student to improve their academic engagement, which was measured by monitoring the number of prompts required to keep the students on task. Teacher and student interviews indicated high levels of satisfaction with using the iPad for language arts instruction.

Scholars in China and foreign countries mainly discussed the application of multimedia, interactive electronic whiteboard, virtual reality technology in teaching from the perspective of research content .The application of digital technology and mobile technology to English teaching for hearing impaired student is also examined. Teaching grammar, vocabulary and reading is the third research point. From what is discussed above, there are three defects in the research previously: the first is that teaching is the research focus while learning is neglected; the second is that micro-research is the priority while macro-research is seldom done. The third is that research type on new media is not sufficient.

\section{Design, Method AND SETtingS}

\section{A. Design and Method}

This project selects 12 hearing impaired students in grade 11 in special education school. Before training their reading and writing, we give them a reading and writing test. Then, the score is recorded. After the test, students are provided with smart cell phone or Ipad. Teacher starts the training of their reading and writing in 3 months. After the training, students will be tested again. Then, pre-training test score of reading and writing and post-training test score will be compared and analyzed. An interactive learning and teaching mode between teacher and student is constructed as follows. 


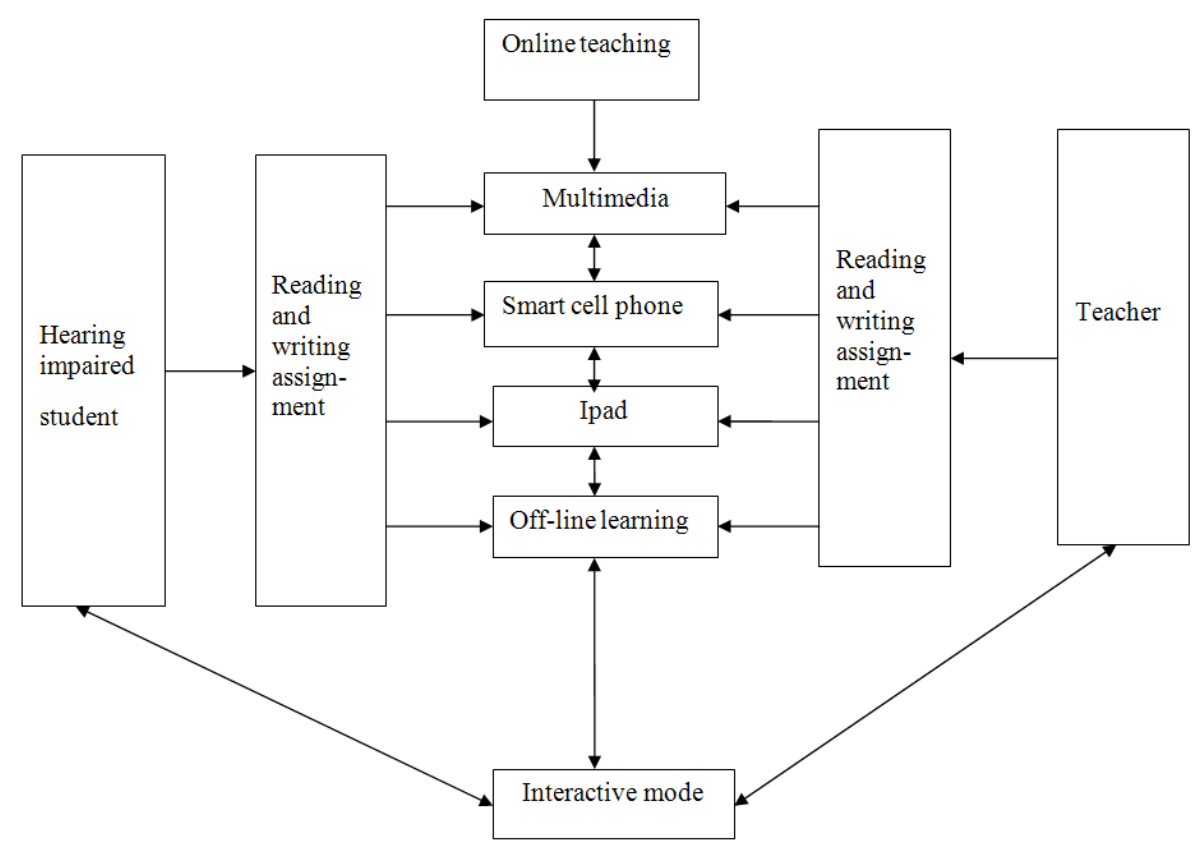

An interactive learning and teaching mode between teacher and student

\section{B. Settings}

TABLE 1

DESCRIPTION OF THE STUDENT

\begin{tabular}{|l|l|l|l|l|}
\hline student & age & gender & nationality & grade level \\
\hline 1 & 17 & Female & Han & 11 \\
\hline 2 & 18 & Female & Han & 11 \\
\hline 3 & 20 & Female & Han & 11 \\
\hline 4 & 17 & Male & Han & 11 \\
\hline 5 & 18 & Male & Han & 11 \\
\hline 6 & 19 & Female & Han & 11 \\
\hline 7 & 17 & Female & Han & 11 \\
\hline 8 & 18 & Female & Han & 11 \\
\hline 9 & 17 & Female & Han & 11 \\
\hline 10 & 18 & Male & Han & 11 \\
\hline 11 & 18 & Male & Han & 11 \\
\hline 12 & 18 & Male & Han & 11 \\
\hline
\end{tabular}

A general description of the student: 12 students will participate in the test. Among them, seven are female students, and five are male students. Their nationality is Han ethnic group. They are grade 11 in a special education school.

\section{RESUlts}

A. Does the New Media Intervention Improve Hearing Impaired Student's English Reading or Writing Skills?

TABLE 2

ENGLISH READING AND WRITING TEST FOR HEARING IMPAIRED STUDENTS

\begin{tabular}{|l|l|l|}
\hline Student & Pre-training test score & Post-training test score \\
\hline 1 & 22 & 31 \\
\hline 2 & 16 & 19 \\
\hline 3 & 11 & 17 \\
\hline 4 & 8 & 22 \\
\hline 5 & 12 & 19 \\
\hline 6 & 29 & 32 \\
\hline 7 & 26 & 18 \\
\hline 8 & 11 & 15 \\
\hline 9 & 16 & 12 \\
\hline 10 & 2 & 11 \\
\hline 11 & 15 & 17 \\
\hline 12 & 20 & 18 \\
\hline
\end{tabular}

The total score of reading and writing is 40 points.

Dada analysis 
It can be seen from the table that three students' score of reading and writing declines and nine increases. By comparing and analyzing pre-training test score of reading and writing and post-training test score, it is obvious that the new media intervention improves hearing impaired student's English reading and writing skills For those score that declines, there is one possibility that the three students don't make good use of new media. They may use smart phone or ipad for entertainment, or at least they didn't use them for academic purpose.

B. Does the New Media Improve Teaching and Learning Effectiveness for Teacher and Hearing Impaired Student?

TABLE 3

EFFECTIVENESS OF USING NEW MEDIA IN LEARNING ENGLISH FOR STUDENTS

\begin{tabular}{|l|l|l|l|l|}
\hline Survey item & Response Option & Wonthly & Weekly & Daily \\
\cline { 3 - 5 } & Never & Mon & \\
\hline How often do you use smart phone for reading & & & $\sqrt{ }$ & \\
\hline How often do you text message in English? & & & & \\
\hline How often do you visit English websites? & $\sqrt{ }$ & & & $\sqrt{ }$ \\
\hline How often do you use apps for English reading or writing? & & & & \\
\hline
\end{tabular}

Dada analysis

It is very difficult for impaired students to learn English and visit websites Being afraid of difficulty and laziness are two of impaired student's most arresting feature, so they don 't like to visit English websites. During reading and writing training, teacher shares English text and check homework through WeChat and QQ, so students have to use smart phone for reading, and text message in English weekly. In English class, teacher connect phone to computer to show text, so students use apps for English reading and writing daily. However, some students use smart phone for entertainment in their spare time. For those students new media may interfere with their English learning. On the whole, using new media in learning English is more or less effective for most students.

TABLE 4

EFFECTIVENESS OF USING NEW MEDIA IN TEACHING ENGLISH FOR TEACHER

\begin{tabular}{|l|l|l|l|l|}
\hline Survey item & Response-Option & Wonthly & Weekly & Daily \\
\cline { 2 - 5 } & Never & Mon & $\sqrt{ }$ \\
\hline How often do you use smart phone for preparation? & & & & \\
\hline How often do you text message in English? & & & $\sqrt{ }$ & \\
\hline How often do you visit English websites? & & & $\sqrt{ }$ & $\sqrt{ }$ \\
\hline How often do you use apps for English reading or writing? & & & & \\
\hline
\end{tabular}

Dada analysis

Teachers use smart phone to teach students, so they use smart phone for teaching preparation and use apps for English reading or writing daily. They search English text in English websites for impaired students to practice reading and text message in English to communicate with students weekly. In a word, using new media in Teaching English for teachers is very effective.

\section{What Are the Advantages of and Challenges to Using New Media for Classroom Instruction and Learning?}

This question was done by using informal observations, interviews, and self-report surveys.

Advantages. Both teacher and students are interviewed and they offer their own observations about advantages of using new media for classroom instruction. Most teacher and student are positive about using new media, such as multimedia, smart cell phone or Ipad in teaching or learning English. There are four advantages as follows:

Interactive .Through using new media online or offline in instruction, teacher and student can interact with each other conveniently. When student has a question after class, they may ask the teacher online through smart cell phone or Ipad without the restriction of time and space. Teacher will answer it quickly.

Effective .Student can read and write English effectively with the help of Ipad, Wechat, QQ, and other mobile apps.

Motivated. By using new media, students are motivated by the colorful, multifaceted content. Students visual attention is attracted by the colorful and varied pictures and diagrams.

Vivid. Through ppt demonstration, teacher makes full use of students' visual function. The class instruction becomes vivid and can be easily accepted by the hearing impaired students.

Challenges. On the other hand, teachers and students also mentioned challenges they face in using new media. Three challenges are mentioned as follows:

A high level of technical support was needed throughout the training, indicating that staff would need additional training and support in the classroom if iPads or cell phone were to be used in instruction. Patricia O'Malley (2014)

Results revealed that hearing impaired students had a variety of technology available after class but the students generally had limited use. When students did have access, they used primarily for entertainment reasons and not for learning purposes.

Logistical issues were evident throughout the training. It took more time and effort than originally thought to oversee the use, storage, and maintenance of the iPads and multimedia. 


\section{DISCUSSION}

As discussed above, an interactive learning and teaching mode between teacher and student is constructed in the training. Results show that the new media intervention improves hearing impaired student's English reading or writing skills. Students and teachers are likely to use new media in their teaching and learning. The new media improves teaching and learning effectiveness a lot. Advantages and challenges do exist in using new media both for teachers and students.

New media is a very effective tool in classroom instruction and off-line learning. However, every coin has two sides. If teacher overuses the new media, he or she will neglect the essence of teaching. Students use too much new media not for learning purpose, but for entrainment, the consequences will be very severe. So the using of new media for hearing impaired student should be under supervision. The supervision in class is easy. However, the supervision after class or in students' spare time is difficult to control, which poses a challenging problem for English teachers.

\section{ACKNOWLEDGEMENTS}

This paper is supported by a grant from "Scientific Research Development Plan Project, Leshan Normal University"(Project name: A Study on the Training of English Reading and Writing Competence for Hearing Impaired Student on the Basis of New Media; Project number:S16015). This paper is also supported by a grant from Sichuan Social Science Planning Office,(Project name: A Study on the Learning Mode of English Reading and Writing for Hearing Impaired Student on the Basis of New Media_— Taking Senior High Students in Special Education School as an Example, Project number SC17XK031)

\section{REFERENCES}

[1] Camille Rogers and Bruce Rogers. (2013). Using IPADS to Assist Students with Special Needs: A Preliminary Overreview. Special Education Apps, Proceedings of the Southern Association for Information Systems Conference, Savannah, GA, USA March 8th-9th, 176-178.

[2] Chen Ruojing. (2015). On the Creativity of English Education in the Era of New Media. Journal of Inner Mongolia Normal University (Educational Science), 10,133-134.

[3] He Gaoda. (2014). Key Problems of Second Language Acquisition in Visual Learning. Computer-assisted Foreign Language Education, 1, 27-32.

[4] Li Xiang. (2014). A Study of Special Education English Teacher Professional Development on the Basis of Constructivism. China Adult Education, 13, 122-124.

[5] Patricia O'Malley et al. (2014). Effectiveness of Using iPads to Increase Academic Task Completion by Students with Autism. Universal Journal of Educational Research 1, 90-97.

[6] Song Bo. (2012). The Application of Interactive Whiteboard Deaf School English Teaching. China Educational Technology and Equipment, 6, 23-24.

[7] Sun Zhifang, Hu Haiyan, Zhou Bochun. (2012). Effective Combination of Multimedia Technology and Deaf and Dumb Students' English Learning. China Educational Technology and Equipment, 2,126-130.

[8] Therese M. Cumming. (2013). Integrating the iPad into Language Arts Instruction for Students with Disabilities: Engagement and Perspectives. Journal of Special Education Technology, 28(4), 43-52.

[9] Tu Chunlei. (2006).Improving Hearing Impaired Students Linguistic Competence in Information Technology Course. Modern Special Education, 12, 20-21.

[10] Wang Xincheng. (2014). An Analysis of Effective English Teaching for Hearing Impaired Students. Overseas English, 12, $24-$ 56.

[11] Wang Zhengsheng. (2014). A Review of Researches into English Teaching for Deaf Students in China Chinese. Journal of Special Education, 3, 17-23.

[12] Xue Qing. (2012). On the Function of Multimedia in Hearing Impaired Students English Teaching. Read and Write Periodical, 12,191-192.

[13] Yu Jing. (2015). On the English Teaching in Deaf School in the Environment of Mobile Terminal. A Journal of Modern Special Education, 11, 56-58.

[14] Zhang Songbai. (2009). A Study on the Effects of Hearing Impairment on English Learning of the Deaf in China and the Implication for Teaching. Chinese Journal of Special Education (Monthly), 3,33-37.

[15] Zhao Chunhui and Hu Zhenbo. (2015) The Current Situation of Born Deaf English Learning and the Use of the Multimedia Technology in China. Journal of Jilin Jianzhu University, 4, 99-101.

[16] Zheng Xuan. (2016). My View on Strategies for Hearing Impaired Students English Learning. Modern Special Education, 7 , 60-61.

[17] Zhou Lin. (2016) .Using Internet to Open Another Window of English Reading for Hearing Impaired Students. Zhejiang Educational Technology, 1, 42-43; 58.

[18] Zhu Lei and Xin Wei. (2013).The Application and Practice of Virtual Reality Technology in English Project Learning for Hearing Impaired Students. Journal of Educational Institute of Jilin Province,6,153-154.

[19] Zou Xiaowei. (2014). An Innovative Study of Course Teaching Mode for English Major in the Era of New Media. Journal of Inner Mongolia Normal University (Educational Science), 12, 113-114. 
Bo Xu was born in Fangxian, Shiyan, China. He received his MA degree in Foreign Linguistics and Applied Linguistics in Guangxi University, China in 2009.He is currently an associate professor of School of Foreign Languages, Leshan Normal University. His research interests include functional linguistics and applied linguistics. 